\title{
Epidemiology of Frontotemporal Lobar Degeneration in Northern Finland
}

\author{
Laura Luukkainen $^{\mathrm{a}, \mathrm{b}}$ Risto Bloigu ${ }^{\mathrm{c}}$ Virpi Moilanen ${ }^{\mathrm{b}}$ \\ Anne Marja Remes ${ }^{d}$ e \\ ${ }^{a}$ Department of Neurology, Institute of Clinical Medicine, University of Oulu, ${ }^{b}$ Department \\ of Neurology, Oulu University Hospital, and 'Medical Informatics Group, University of Oulu, \\ Oulu, and d Department of Neurology, Institute of Clinical Medicine, University of Eastern

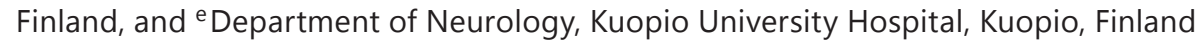

\author{
Key Words \\ Epidemiology Prevalence Incidence $\cdot$ Behavioral variant · Frontotemporal dementia . \\ Semantic dementia - Progressive nonfluent aphasia
}

\section{Abstract}

Background: Frontotemporal lobar degeneration (FTLD) is responsible for as many as every fifth case of early-onset dementia. Very few epidemiological studies of FTLD have been conducted; there are no published epidemiological data of FTLD from Finland or the other Nordic countries. The C9ORF72 expansion-associated FTLD is common in Finland; thus, the prevalence of FTLD is expected to be high in this population. Methods: We retrospectively evaluated the incidence and prevalence of FTLD in university hospital settings in Northern Finland. Results: The mean 1-year incidence of FTLD was 5.54/100,000 (range 1.9-11.3/100,000) in the population aged 45-65 years. The prevalence of FTLD in the same age group was 20.5/100,000. Conclusion: The incidence and prevalence of FTLD in Finland seem to be the highest in Europe. However, studies from different countries may not be directly mutually comparable due to methodological issues.

(c) 2015 S. Karger AG, Basel

\section{Introduction}

Frontotemporal lobar degeneration (FTLD) is the second most common degenerative dementing disease; it is thought to be responsible for $10-20 \%$ of patients with early-onset dementia (onset under the age of 65 years). FTLD is divided into three clinical syndromes: behavioral variant frontotemporal dementia (bvFTD), semantic dementia and progressive 
Table 1. Previously published studies investigating the incidence of FTLD

\begin{tabular}{|c|c|c|c|c|c|c|c|c|}
\hline Study & $\begin{array}{l}\text { Study area, } \\
\text { country }\end{array}$ & $\begin{array}{l}\text { Inhabitants } \\
\text { in the study } \\
\text { area }\end{array}$ & Study population & $\begin{array}{l}\text { Cases with } \\
\text { different types } \\
\text { of FTLD }\end{array}$ & $\begin{array}{l}\text { Age } \\
\text { group(s), } \\
\text { years }\end{array}$ & $\begin{array}{l}\text { Study time } \\
\text { period/ } \\
\text { census day }\end{array}$ & $\begin{array}{l}\text { Diagnostic } \\
\text { criteria }\end{array}$ & $\begin{array}{l}\text { Incidence } / 100,000 \\
(95 \% \text { confidence interval) }\end{array}$ \\
\hline $\begin{array}{l}\text { Knopman } \\
\text { et al. [18], } \\
2011\end{array}$ & $\begin{array}{l}\text { Rochester, Minn., } \\
\text { USA }\end{array}$ & NA & $\begin{array}{l}60 \text { patients with } \\
\text { dementia onset }<70 \text {, } \\
\text { and } 504 \text { cases }>70, \\
\text { and } 114 \text { autopsied } \\
\text { cases }\end{array}$ & 4 FTLD & $40-69$ & $1990-1994$ & $\begin{array}{l}\text { Neary et al. } \\
{[1]}\end{array}$ & $4.1(1.1-10.4)$ \\
\hline $\begin{array}{l}\text { Mercy } \\
\text { et al. [16], } \\
2008\end{array}$ & $\begin{array}{l}\text { Cambridge City, } \\
\text { East Cambridge- } \\
\text { shire and South } \\
\text { Cambridgeshire, } \\
\text { England, UK }\end{array}$ & 326,200 & $\begin{array}{l}54 \text { new dementia } \\
\text { cases }\end{array}$ & $\begin{array}{l}12 \text { bvFTD } \\
1 \text { FTD-MND } \\
2 \text { SD } \\
1 \text { PFNA }\end{array}$ & $45-64$ & $\begin{array}{l}2000-2006 / \\
\text { the census popu- } \\
\text { lation estimates } \\
\text { from } 2003\end{array}$ & $\begin{array}{l}\text { Neary et al. } \\
{[1]}\end{array}$ & $3.5(2.0-5.7)$ \\
\hline $\begin{array}{l}\text { Garre- } \\
\text { Olmo } \\
\text { et al. [17], } \\
2010\end{array}$ & $\begin{array}{l}\text { Girona, Catalonia, } \\
\text { Spain }\end{array}$ & 690,207 & $\begin{array}{l}2,083 \text { new dementia } \\
\text { cases from the } \\
\text { ReDeGi register }\end{array}$ & $\begin{array}{l}56 \text { bvFTD } \\
14 \mathrm{SD}\end{array}$ & $\begin{array}{l}30-64 \\
>65\end{array}$ & $\begin{array}{l}2007-2009 / \\
\text { the census popu- } \\
\text { lation estimates } \\
\text { from every year }\end{array}$ & - & $\begin{array}{l}<65: 1.3(0.7-2.2) \\
\text { bvFTD: } 1.2(0.6-2.1) \\
\text { SD: } 0.1(<0.01-0.5) \\
>65: 16.7(12.6-21.7) \\
\text { bvFTD: } 12.8(9.3-17.3) \\
\text { SD: } 3.9(2.0-6.6)\end{array}$ \\
\hline $\begin{array}{l}\text { Present } \\
\text { study }\end{array}$ & $\begin{array}{l}\text { Finland, Northern } \\
\text { Ostrobothnia }\end{array}$ & 398,355 & $\begin{array}{l}40 \text { patients with } \\
\text { FTLD }\end{array}$ & $\begin{array}{l}34 \text { bvFTD } \\
1 \text { FTD-ALS } \\
2 \text { SD } \\
1 \text { PFNA }\end{array}$ & $45-70$ & $\begin{array}{l}2006-2010 / \\
\text { December 31, } \\
2010\end{array}$ & $\begin{array}{l}\text { Neary et al. } \\
\text { [1], Rascov- } \\
\text { sky et al. [7], } \\
\text { Gorno-Tem- } \\
\text { pini et al. [8] }\end{array}$ & $\begin{array}{l}45-70: 6.7 \text { (range } 4.1-11.5 \text { ) } \\
45-65: 5.54 \text { (range } 1.9-11.3 \text { ) }\end{array}$ \\
\hline
\end{tabular}

NA = Not available; FTD-MND = frontotemporal dementia with motor neuron disease; SD = semantic dementia; PFNA = progressive nonfluent aphasia; FTDALS = frontotemporal dementia with amyotrophic lateral sclerosis.

nonfluent aphasia [1]. The presence of different pathologies and genetic backgrounds is the basis for allocation to the clinical syndromes [2]. There have been very few epidemiological studies conducted focusing on FTLD, and the epidemiology has been studied mainly in the age group of under 65-year-olds (table 1,2). These studies have been conducted with different study designs, and this may explain why there are such extensive variations in the reported prevalence of FTLD from several European studies (4.0-29.9/100,000; table 1) [3-5]. There have been no previous epidemiological data of FTLD from any of the Nordic countries. In Finland, the C9ORF72 expansion-associated FTLD is rather common [6], thus prevalence of FTLD would be expected to be high in this population. The aim of this study was to evaluate the prevalence and 1-year incidence of FTLD in the Finnish population.

\section{Methods}

Northern Ostrobothnia is a province in the north of Finland with a population of 398,355 on December 31, 2010, i.e. $7.4 \%$ of the total population of Finland. The female/male ratio was 0.99. This study was conducted at the outpatient memory clinic of the Department of Neurology of Oulu University Hospital (OUH) with the approval of the Ethics Committee of the Northern Ostrobothnia Hospital District following the principles of the Declaration of Helsinki. The OUH is the primary referral center for all patients under 70 years with memory or cognitive complaints. Patients over 70 years with memory/cognitive complaints were excluded from the study as they are mainly referred to other local memory clinics.

The data were collected from the hospital discharge register using the ICD-10 diagnoses G31.0 and F03, and the exact date of the diagnosis was confirmed to be within the time frame of January 1, 2006-December 31, 2010. All patients underwent a full neurological exami- 
Table 2. Previously published studies investigating the prevalence of FTLD

\begin{tabular}{|c|c|c|c|c|c|c|c|c|}
\hline Study & $\begin{array}{l}\text { Study area, } \\
\text { country }\end{array}$ & $\begin{array}{l}\text { Inhabitants } \\
\text { in the study } \\
\text { area }\end{array}$ & $\begin{array}{l}\text { Study } \\
\text { population }\end{array}$ & $\begin{array}{l}\text { Cases with } \\
\text { different types of } \\
\text { FTLD }\end{array}$ & $\begin{array}{l}\text { Age } \\
\text { group, } \\
\text { years }\end{array}$ & $\begin{array}{l}\text { Study time } \\
\text { period/ } \\
\text { census day }\end{array}$ & $\begin{array}{l}\text { Diagnostic } \\
\text { criteria }\end{array}$ & $\begin{array}{l}\text { Prevalence } / 100,000 \\
\text { (95\% confidence interval) }\end{array}$ \\
\hline $\begin{array}{l}\text { Ratnavalli } \\
\text { et al. [5], } \\
2002\end{array}$ & $\begin{array}{l}\text { Cambridge City, } \\
\text { East Cambridge- } \\
\text { shire and South } \\
\text { Cambridgeshire, } \\
\text { England, UK }\end{array}$ & 326,019 & $\begin{array}{l}108 \text { cases of } \\
\text { early-onset } \\
\text { dementia }\end{array}$ & 11 FTD & $45-64 *$ & $\begin{array}{l}1997-2000 / \\
\text { May } 30,2000\end{array}$ & $\begin{array}{l}\text { Neary et al. } \\
{[1]}\end{array}$ & $45-64: 15.1(8.4-27.0)$ \\
\hline $\begin{array}{l}\text { Harvey } \\
\text { et al. [4], } \\
2003\end{array}$ & $\begin{array}{l}\text { The London } \\
\text { boroughs of } \\
\text { Kensington, Chelsea, } \\
\text { Westminster and } \\
\text { Hillingdon, England, } \\
\text { UK }\end{array}$ & 567,500 & $\begin{array}{l}185 \text { patients } \\
\text { with early- } \\
\text { onset dementia }\end{array}$ & 23 FTD & $30-64$ & NA & $\begin{array}{l}\text { Lund and } \\
\text { Manchester } \\
{[20]}\end{array}$ & $\begin{array}{l}30-64: 7.5(4.4-11.8) \\
45-64: 15.4(9.1-24.3)\end{array}$ \\
\hline $\begin{array}{l}\text { Rosso } \\
\text { et al. [12], } \\
2003\end{array}$ & $\begin{array}{l}\text { The province of } \\
\text { Zuid-Holland, The } \\
\text { Netherlands }\end{array}$ & $2,043,949$ & $\begin{array}{l}245 \text { patients } \\
\text { with probable } \\
\text { FTD }\end{array}$ & 174 FTD & $30-79$ & $\begin{array}{l}\text { 1994-2002/ } \\
\text { January 1, } 1998\end{array}$ & $\begin{array}{l}\text { Lund and } \\
\text { Manchester } \\
{[20]}\end{array}$ & $\begin{array}{l}40-49: 1.2(0.6-2.7) \\
50-59: 3.6(2.1-6.0) \\
60-69: 9.4(6.4-13.8) \\
70-79: 3.8(1.9-7.4) \\
\text { overall prevalence: } 2.7(2.1-3.5)\end{array}$ \\
\hline $\begin{array}{l}\text { Borroni } \\
\text { et al. [3], } \\
2011\end{array}$ & $\begin{array}{l}\text { Brescia County, } \\
\text { Northern Italy }\end{array}$ & NA & $\begin{array}{l}94 \text { patients } \\
\text { with FTLD }\end{array}$ & 94 FTLD & $45-65$ & $\begin{array}{l}\text { since 2000/ } \\
\text { December 1, } \\
2009\end{array}$ & $\begin{array}{l}\text { Neary et al. } \\
{[1]}\end{array}$ & $29.6(23.7-35.6)$ \\
\hline $\begin{array}{l}\text { Bernardi } \\
\text { et al. [14], } \\
2012\end{array}$ & $\begin{array}{l}\text { Community in } \\
\text { Biv., Province of } \\
\text { Reggio Calabria, } \\
\text { Italy }\end{array}$ & 1,568 & $\begin{array}{l}30 \text { patients } \\
\text { with dementia }\end{array}$ & 18 FTD & $\geq 50$ & $\begin{array}{l}-/ \text { January } 1, \\
2004\end{array}$ & NA & overall prevalence: 35 \\
\hline $\begin{array}{l}\text { Gilberti } \\
\text { et al. [15], } \\
2012\end{array}$ & $\begin{array}{l}\text { Vallemonica } \\
\text { Valley in the } \\
\text { Province of } \\
\text { Brescia, Northern } \\
\text { Italy }\end{array}$ & 119,647 & $\begin{array}{l}42 \text { patients } \\
\text { with FTLD }\end{array}$ & $\begin{array}{l}34 \text { bvFTD } \\
1 \text { SD } \\
7 \text { PNFA }\end{array}$ & $\geq 45$ & $\begin{array}{l}\text { since } 2000 / \\
\text { January } 1\end{array}$ & $\begin{array}{l}\text { Neary et al. } \\
{[1]}\end{array}$ & $\begin{array}{l}45-65: 31(20-42) \\
66-75: 156(131-180) \\
>75: 135(112-158) \\
\text { overall prevalence: } 35(26-46)\end{array}$ \\
\hline $\begin{array}{l}\text { Wada- } \\
\text { Isoe et al. } \\
{[13]} \\
2012 \\
\end{array}$ & $\begin{array}{l}\text { Tottori } \\
\text { prefecture, } \\
\text { Japan }\end{array}$ & 587,722 & $\begin{array}{l}66 \text { patients } \\
\text { with FTLD }\end{array}$ & $\begin{array}{l}62 \text { bvFTD } \\
3 \text { PNFA } \\
1 \text { SD }\end{array}$ & $\geq 45$ & $\begin{array}{l}-/ \text { October } 1 \\
2010\end{array}$ & $\begin{array}{l}\text { Neary et al. } \\
{[1]}\end{array}$ & $\begin{array}{l}45-55: 4.0(-5.3 \text { to } 8.6) \\
55-64: 5.6(0.7-10.5) \\
\geq 45: 20.7(15.7-26.0) \\
\text { overall prevalence: } 11.2\end{array}$ \\
\hline $\begin{array}{l}\text { Present } \\
\text { study }\end{array}$ & $\begin{array}{l}\text { Finland, } \\
\text { Northern } \\
\text { Ostrobothnia }\end{array}$ & 398,355 & $\begin{array}{l}40 \text { patients } \\
\text { with FTLD }\end{array}$ & $\begin{array}{l}34 \text { bvFTD } \\
1 \text { FTD-ALS } \\
2 \text { SD } \\
1 \text { PFNA }\end{array}$ & $45-70$ & $\begin{array}{l}2006-2010 / \\
\text { December 31, } \\
2010\end{array}$ & $\begin{array}{l}\text { Neary et al. } \\
\text { [1], Rascov- } \\
\text { sky et al. [7], } \\
\text { Gorno-Tem- } \\
\text { pini et al. [8] }\end{array}$ & $\begin{array}{l}45-70: 26.8(18.5-37.6) \\
45-65: 20.5(12.8-31.0)\end{array}$ \\
\hline
\end{tabular}

NA = Not available; SD = semantic dementia; PNFA = progressive nonfluent aphasia; FTD-ALS = frontotemporal dementia with amyotrophic lateral sclerosis * Patients in whom dementia was diagnosed before they were 65 years old but who were older on the census day were included in the study.

nation, evaluation of behavioral and neuropsychiatric symptoms and structural brain imaging. A neuropsychological examination was conducted in $96 \%(n=42)$ of patients. Neuropsychological tests were initially carried out as a part of the clinical diagnostics, and therefore, no uniform neuropsychological test battery was applied. However, concentration, executive function, verbal knowledge, literacy, verbal memory, nonverbal knowledge, nonverbal memory, spatial orientation, constructive and fine motor skills were evaluated with appropriate tests. After the examinations, the diagnoses of FTLD were made by neurologists specializing in memory disorders and were based on the consensus criteria by Neary et al. [1] from 1998. All of the cases also fulfilled the revised criteria for bvFTD prepared by the International Behavioural Variant FTD Criteria Consortium (FTDC) or the criteria for progressive aphasias in retrospective evaluation [7, 8]. Possible or probable Alzheimer's disease was excluded by applying the criteria of the National Institute of Neurological Disorders and Communicative Disorders - Alzheimer's Disease and Related Disorders Association (NINCDSADRDA), and vascular dementia was excluded by applying the criteria proposed by the National Institute of Neurological Disorders and Stroke (NINDS) and the Association Interna- 
Table 3. One- and 5-year incidence of FTLD in the population of the 45- to 65-year-old people living in Northern Ostrobothnia

\begin{tabular}{llcll}
\hline Year & $\begin{array}{l}\text { Population } \\
(45-65 \text { years old })\end{array}$ & $\begin{array}{l}\text { New FTLD cases } \\
(45-65 \text { years old })\end{array}$ & $\begin{array}{l}\text { Incidence/ } \\
100,000\end{array}$ & $\begin{array}{l}\text { Confidence } \\
\text { interval }\end{array}$ \\
\hline 2006 & 102,212 & 9 & 8.81 & $4.03-16.72$ \\
2007 & 102,832 & 3 & 2.92 & $0.60-8.53$ \\
2008 & 104,983 & 3 & 2.86 & $0.59-8.35$ \\
2009 & 106,193 & 12 & 11.30 & $5.84-19.74$ \\
2010 & 107,516 & 2 & 1.86 & $0.23-6.72$ \\
$2006-2010$ & 523,736 & 29 & 5.54 & $3.71-7.95$ \\
\hline
\end{tabular}

tionale pour la Recherche et l'Enseignement en Neurosciences (AIREN). The clinically borderline cases which did not fulfill exactly Neary et al.'s criteria and those patients with concomitant symptoms more typical of the other dementias were excluded.

The data were processed with IBM SPSS Statistics for Windows (versions 20.0. and 21.0., IBM Corp., Armonk, N.Y., USA, released in 2011 and 2012). The 1-year incidence in the age group of 45- to 70-year-olds was calculated using the population of Northern Ostrobothnia on December 31 in the time frame 2006-2010. These values were extracted from the free database of Statistics Finland. The confidence intervals were calculated using Confidence Interval Analysis (CIA) software, version 2.0.0. The prevalence rates were calculated using the population of Northern Ostrobothnia on December 31,2010. All patients who were diagnosed within the time frame of January 1,2006-December 31, 2010 and who were confirmed to be alive according to the patient records on December 31, 2010 were included in the prevalence rates.

\section{Results}

During the 5-year period, a total of 40 new FTLD diagnoses were made at OUH. The majority of patients were diagnosed with bvFTD $(90 \%, \mathrm{n}=36)$. Semantic dementia was diagnosed in $2(5 \%)$ cases, and there was 1 subject with progressive nonfluent aphasia and 1 with FTD with motor neuron disease in the study group. The female/male ratio of the patients was 1.4. The mean age at disease onset was 58.4 years (range 47-67), and the mean age at diagnosis was 61.7 years (range 50-70). During the study period, 29 new FTLD diagnoses were made in the 45- to 65-year age group. DNA samples were available from $34 \%(n=10)$ of these early-onset FTLD cases. Mutations of microtubule-associated protein tau (MAPT), progranulin (PGRN) and charged multivesicular body protein 2b (CHMP2B) as well as the presence of the C90RF72 expansion had been analyzed from these cases in our previous studies [6, 9-11]. No mutations in MAPT, PGRN or CHMP2B were detected in this cohort, but $40 \%(n=4)$ of genetically studied cases were C9ORF72 expansion carriers.

The mean annual incidence of FTLD was 5.54/100,000 (range 1.9-11.3/100,000), and the prevalence was $20.5 / 100,000$ (confidence interval 12.8-31.0) in the population aged 45-65 years (table 3,4). The mean annual incidence was 6.7/100,000 (range 4.1-11.5/10,000), and the prevalence was $26.8 / 100,000$ (confidence interval 18.5-37.6) in the population of 45-70 years. 
Table 4. Prevalence of FTLD in Northern Ostrobothnia

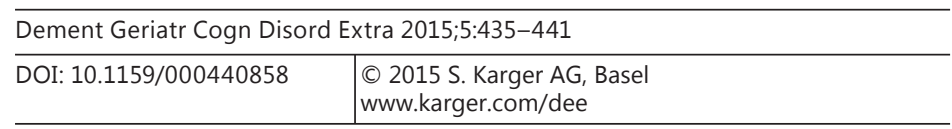

Luukkainen et al.: Epidemiology of Frontotemporal Lobar Degeneration in Northern Finland

\begin{tabular}{llll}
\hline $\begin{array}{l}\text { Age group, } \\
\text { years }\end{array}$ & $\begin{array}{l}\text { Population of the } \\
\text { research area }\end{array}$ & FTLD cases alive & $\begin{array}{l}\text { Prevalence/ } \\
100,000\end{array}$ \\
\hline $45-65$ & 107,516 & 22 & 20.5 \\
$45-70$ & 123,111 & 33 & 26.8 \\
$<65$ & 341,164 & 22 & 6.5 \\
$<70$ & 356,759 & 33 & 9.3 \\
\hline
\end{tabular}

\section{Discussion}

Recently, there has been increasing interest focused on FTLD because of new neuropathological and genetic findings about this disease group. However, there are very little epidemiological data about FTLD, and even in the published reports, the study designs and the age distribution have been variable. Surprisingly, there are no previous epidemiological data on FTLD from any of the Nordic countries. Our hypothesis was that FTLD would be more common in the Finnish population compared to other European populations because the frequency of C9ORF72 expansion-associated FTLD is very high in the Finnish population, although other genetic causes of FTLD in the Finnish population are rare [9-11]. We found that the prevalence of FTLD was $20.5 / 100,000$ in the group aged 45-65 years. The prevalence of FTLD is higher in Finland than in England $(15 / 100,000)$, the Netherlands $(4.0-6.7 / 100,000)$ or Japan $(4.8 / 100,000)$ in the same age group $[4,5,12,13]$. The highest prevalence of FTLD has been reported from Italy $(22-29.6 / 100,000)[3,14,15]$. In the present study, the mean of the 5-year incidence of FTLD was 5.5/100,000 per year in the group aged 45-65 years, which is also slightly higher than in the published values for FTLD in England (3.5/100,000) or bvFTD and semantic dementia in Spain $(1.3 / 100,000)[16,17]$. The prevalence of FTLD in the USA $(15-22 / 100,000)$ is about the same as the Finnish figures [18].

In the previous studies, the overall prevalence of FTLD in all age groups has varied from $2.7 / 100,000$ in the Netherlands to $35 / 100,000$ in Italy $[12,14,15]$. In the Finnish population, the prevalence of FTLD over a broader age range (the age group of 45-70 years) was $26.8 / 100,000$, which is lower than in other European countries such as Germany $(47.9 / 100,000)$ and Italy $(35 / 100,000)$ [19]. However, the varying study designs and different age distributions in these study populations make it difficult to conduct a valid comparison.

As all patients under the age of 65 years with memory disorders in this region are examined and diagnosed at $\mathrm{OUH}$, these results can be considered to be reliable, especially those related to the age group of 45- to 65-year-olds. There is, however, a possibility that the number of FTLD patients has been underestimated and some cases have been misdiagnosed as a psychiatric disorder or some other dementia. Another reason for underestimation is that we excluded all of those cases which did not totally fulfill the FTLD clinical criteria. In contrast, we would argue that overestimation is unlikely. The weaknesses of our study are the lack of genetic information and neuropathological evaluation in the whole cohort as well as the relatively short study period.

In conclusion, this is the first epidemiological study of FTLD from any of the Nordic countries. We found the prevalence rates to be in line with the previous European studies, whereas the annual incidence rates were slightly higher in the group aged less than 65 years. Further studies with larger populations with genetically or neuropathologically confirmed diagnoses will be needed to clarify the epidemiology of FTLD in European countries. 


\section{Acknowledgments}

This work was supported in part by the EVO grants from Kuopio University Hospital.

\section{Disclosure Statement}

The authors disclose no conflicts of interest.

\section{References}

1 Neary D, Snowden JS, Gustafson L, Passant U, Stuss D, Black S, Freedman M, Kertesz A, Robert PH, Albert M, Boone K, Miller BL, Cummings J, Benson DF: Frontotemporal lobar degeneration: a consensus on clinical diagnostic criteria. Neurology 1998;51:1546-1554.

-2 Haapasalo A, Remes AM: Genetic and molecular aspects of frontotemporal lobar degeneration. Curr Genet Med Rep 2015;3:8-18.

3 Borroni B, Alberici A, Grassi M, Rozzini L, Turla M, Zanetti O, Bianchetti A, Gilberti N, Bonvicini C, Volta GD, Rozzini R, Padovani A: Prevalence and demographic features of early-onset neurodegenerative dementia in Brescia County, Italy. Alzheimer Dis Assoc Disord 2011;25:341-344.

4 Harvey RJ, Skelton-Robinson M, Rossor MN: The prevalence and causes of dementia in people under the age of 65 years. J Neurol Neurosurg Psychiatry 2003;74:1206-1209.

5 Ratnavalli E, Brayne C, Dawson K, Hodges JR: The prevalence of frontotemporal dementia. Neurology 2002; 58:1615-1621.

6 Majounie E, Renton AE, Mok K, Dopper EGP, Waite A, Rollinson S, Chiò A, Restagno G, Nicolaou N, Simon-Sanchez J, van Swieten JC, Abramzon Y, Johnson JO, Sendtner M, Pamphlett R, Orrell RW, Mead S, Sidle KC, Houlden H, Rohrer JD, Morrison KE, Pall H, Talbot K, Ansorge 0; Chromosome 9-ALS/FTD Consortium; French research network on FTLD/FTLD/ALS; ITALSGEN Consortium, Hernandez DG, Arepalli S, Sabatelli M, Mora G, Corbo M, Giannini F, Calvo A, Englund E, Borghero G, Floris GL, Remes AM, Laaksovirta H, McCluskey L, Trojanowski JQ, Van Deerlin VM, Schellenberg GD, Nalls MA, Drory VE, Lu CS, Yeh TH, Ishiura H, Takahashi Y, Tsuji S, Le Ber I, Brice A, Drepper C, Williams N, Kirby J, Shaw P, Hardy J, Tienari PJ, Heutink P, Morris HR, Pickering-Brown S, Traynor BJ: Frequency of the C9orf72 hexanucleotide repeat expansion in patients with amyotrophic lateral sclerosis and frontotemporal dementia: a cross-sectional study. Lancet Neurol 2012;11:323-330.

7 Rascovsky K, Hodges JR, Knopman D, Mendez MF, Kramer JH, Neuhaus J, van Swieten JC, Seelaar H, Dopper EG, Onyike CU, Hillis AE, Josephs KA, Boeve BF, Kertesz A, Seeley WW, Rankin KP, Johnson JK, Gorno-Tempini ML, Rosen H, Prioleau-Latham CE, Lee A, Kipps CM, Lillo P, Piguet O, Rohrer JD, Rossor MN, Warren JD, Fox NC, Galasko D, Salmon DP, Black SE, Mesulam M, Weintraub S, Dickerson BC, Diehl-Schmid J, Pasquier F, Deramecourt V, Lebert F, Pijnenburg Y, Chow TW, Manes F, Grafman J, Cappa SF, Freedman M, Grossman M, Miller BL: Sensitivity of revised diagnostic criteria for the behavioural variant of frontotemporal dementia. Brain 2011;134:2456-2477.

-8 Gorno-Tempini ML, Hillis AE, Weintraub S, Kertesz A, Mendez M, Cappa SF, Ogar JM, Rohrer JD, Black S, Boeve BF, Manes F, Dronkers NF, Vandenberghe R, Rascovsky K, Patterson K, Miller BL, Knopman DS, Hodges JR, Mesulam MM, Grossman M: Classification of primary progressive aphasia and its variants. Neurology 2011; 15:1006-1014.

9 Krüger J, Kaivorinne AL, Udd B, Majamaa K, Remes AM: Low prevalence of progranulin mutations in Finnish patients with frontotemporal lobar degeneration. Eur J Neurol 2009;16:27-30.

10 Kaivorinne AL, Krüger J, Kuivaniemi K, Tuominen H, Moilanen V, Majamaa K, Remes AM: Role of MAPT mutations and haplotype in frontotemporal lobar degeneration in Northern Finland. BMC Neurol 2008;17:8:48.

11 Kaivorinne AL, Krüger J, Udd B, Majamaa K, Remes AM: Mutations in CHMP2B are not a cause of frontotemporal lobar degeneration in Finnish patients. Eur J Neurol 2010;17:1393-1395.

-12 Rosso SM, Donker Kaat L, Baks T, Joosse M, de Koning I, Pijnenburg Y, de Jong D, Dooijes D, Kamphorst W, Ravid R, Niermeijer MF, Verheij F, Kremer HP, Scheltens P, van Duijn CM, Heutink P, van Swieten JC: Frontotemporal dementia in The Netherlands: patient characteristics and prevalence estimates from a populationbased study. Brain 2003;126:2016-2022.

13 Wada-Isoe K, Ito S, Adachi T, Yamawaki M, Nakashita S, Kusumi M, Hiroe Y, Takada T, Watanabe K, Hikasa C, Nakashima K: Epidemiological survey of frontotemporal lobar degeneration in Tottori prefecture, Japan. Dement Geriatr Cogn Dis Extra 2012;2:381-386.

14 Bernardi L, Frangipane F, Smirne N, Colao R, Puccio G, Curcio SA, Mirabelli M, Maletta R, Anfossi M, Gallo M, Geracitano S, Conidi ME, Di Lorenzo R, Clodomiro A, Cupidi C, Marzano S, Comito F, Valentini V, Zirilli MA, Ghani M, Xi Z, Sato C, Moreno D, Borelli A, Leone LA, St George-Hyslop P, Rovaeva E, Bruni AC: Epidemiology and genetics of frontotemporal dementia: a door-to-door survey in southern Italy. Neurobiol Aging 2012;33: 2948.e1-2948.e10. 
15 Gilberti N, Turla M, Alberici A, Bertasi V, Civelli P, Archetti S, Padovani A, Borroni B: Prevalence of frontotemporal lobar degeneration in an isolated population: the Vallecamonica study. Neurol Sci 2012;33:899-904.

16 Mercy L, Hodges JR, Dawson K, Barker RA, Brayne C: Incidence of early-onset dementias in Cambridgeshire, United Kingdom. Neurology 2008;71:1496-1499.

17 Garre-Olmo J, Genis Batlle D, del Mar Fernandez M, Marquez Daniel F, de Eugenio Huelamo R, Casadevall T, Turbau Recio J, Turon Estrada A, Lopez-Pousa S; Registry of Dementia of Girona Study Group (ReDeGi StudyGroup): Incidence and subtypes of early-onset dementia in a geographically defined general population. Neurology 2010;75:1249-1255.

18 Knopman DS, Roberts RO: Estimating the number of persons with frontotemporal lobar degeneration in the US population. J Mol Neurosci 2011;45:330-335.

19 Ibach B, Koch H, Koller M, Wolfersdorf M; Workgroup for Geriatric Psychiatry of the Psychiatric State Hospitals of Germany, Workgroup for Clinical Research of the Psychiatric State Hospitals of Germany: Hospital admission circumstances and prevalence of frontotemporal lobar degeneration: a multicenter psychiatric state hospital study in Germany. Dement Geriatr Cogn Disord 2003;16:253-264.

20 The Lund and Manchester Groups: Clinial and neuropathological criteria for frontotemporal dementia. J Neurol Neurosurg Psychiatry 1994;57:416-418. 